\title{
DEVELOPING A FRAMEWORK OF CORPORATE GOVERNANCE BEST PRACTICE FOR THE MALAYSIAN TOURISM SMALL AND MEDIUM-SIZED ENTERPRISES
}

\author{
Nurhazani MOHD SHARIFF* \\ School of Tourism, Hospitality \& Event Management, COLGIS, University Utara Malaysia \\ o6010, Sintok, Kedah, Malaysia, e-mail: hazani@uum.edu.my \\ Azlan ZAINOL ABIDIN \\ School of Languages, Civilization \& Philosophy, CAS, University Utara Malaysia \\ o6010, Sintok, Kedah, Malaysia, e-mail: azlan@uum.edu.my \\ Mohd Roslee BAHAR \\ Public Islamic Bank \\ Jalan Ampang, Malaysia, e-mail: mohdrosleebahar@gmail.com
}

\begin{abstract}
Citation: Mohd Shariff, N., Zainol Abidin, A., Bahar, R. M. (2018). DEVELOPING A FRAMEWORK OF CORPORATE GOVERNANCE BEST PRACTICE FOR THE MALAYSIAN TOURISM SMALL AND MEDIUM-SIZED ENTERPRISES. GeoJournal of Tourism and Geosites. 22(2), 447-454. https://doi.org/10.30892/gtg.22214-301
\end{abstract}

\begin{abstract}
This paper presents a framework for corporate governance best practice in Malaysia tourism small and medium-sized enterprises (TSMEs). Based on the reviewed literature regarding TSMEs and corporate governance, this paper presents nine major elements of corporate governance best practice in a form of framework namely; Shareholders, Ownership and Board Structure, Top Management, Board of Directors, Conflict of Interest, Stakeholders, Social Responsibility, Remuneration and Transparency. The implementation and adaptation of this framework in managing TSMEs would significantly assist the administration, management and shareholders to accomplish and achieve performance excellence. Additionally, the framework would also contribute as guideline which could be used for further research in determining whether these elements are being practiced by the TSMEs Board of Directors.
\end{abstract}

Key words: Corporate governance best practice, Malaysian tourism small and medium-sized enterprises, framework

\section{INTRODUCTION}

The tourism industry in Malaysia is currently playing an essential role particularly in the country's economy. Thus, it is believed that tourism industry can assist Malaysia to achieve sustained economic growth and contribute to social development through the

\footnotetext{
* Corresponding author
} 
establishment of tourism small and medium-sized enterprises (TSMEs). The definition of small and medium-sized enterprise (SME) varies from country to country. In such a country, for example Egypt, SME is defined as having more than 5 and fewer than 50 employees (Dalberg, 2011). According to Natarajan and Wyrick (2011), countries in Europe define SME as having manpower fewer than 250 employees while in the United States, SME is defined as one with employees fewer than 500 standard definition. Apart from the key role in delivering tourism products to the tourist, TSMEs also play an active role in advancing the local community. Hence, TSMEs performance and survival in the industry are found to be particularly important to Malaysia (Set, 2013). Malaysia is doing its best in promoting tourism industry through TSMEs, for instance, by implementing various TSME programmes and policies. Additionally, the funding for the development allocated to TSMEs has been increasing over the last few years.

The indication that TSMEs play vital component in increasing the country's foreign exchange earning can be seen through the initiative taken by the government by placing high expectations on TSMEs performance. Generally, in 2010, the TSMEs activities in Malaysia had contributed 28.5 per cent to the country's Gross Domestic Product (GDP). Further, the government spent RM 4,677.1 million in the form of 183 trainings and financial programmes in 2011 (Small and Medium Enterprise Corporation Malaysia, 2012). Currently, there are about 239,110 active establishments of TSMEs in Malaysia with 142,721 firms (59.7 per cent) offering food and beverage services, 40,025 firms (16.7 per cent) offering transportation services and other miscellaneous tourism services. Meanwhile, accommodation services, arts, entertainment and recreation services, and travel agency, tour operator and tourism guide services are offered by 19,643 TSMEs (8.2 per cent of total TSMEs). With the increased number of tourist arrivals, the tourism industry in Malaysia has created business potential and diversification of tourism products and services which particularly involved the TSMEs. Hence, TSMEs must achieve high performance in their management through the implementation of good corporate governance practice. The purpose of this study is to identify and investigate major elements which are considered important in the process of practicing corporate governance in TSMEs. Hence, it intends to come out with a framework of corporate governance best practice which can be applied throughout by the management of TSMEs.

\section{LITERATURE REVIEW}

As noted by Chittithaworn et al. (2011), the definition of an SME depends on a country's physical and economic size, cultural situation, government policy, and data collection measures to produce SME statistics. In Malaysia, SMEs are defined based on the number of full-time employees or the total sales or revenue. Similarly, this definition is applied to the tourism industry, under the services category. Compared to a larger company, TSMEs are in a good position to cater to consumers' increasing demand for more personalised services. This is supported by several researchers such as Akbaba (2012) and Sampaio et al. (2012) where they indicated that TSMEs have greater flexibility to adapt their services and products to tourists' changing requirements and preferences compared to larger companies. Hence, standardised tourism products are no longer appealing to consumers, and tourists expect providers to tailor products and services to their specific needs and tastes. According to few other researchers such as Causevic and Lynch (2013), the dominancy of TSMEs in tourism will lead to higher tourist expenditure in the industry. Several studies also supported these findings by highlighting that the predominance of TSMEs will also create prospects for investment, notably in rural areas, and job opportunities for the local community (Narayan et al., 2010; Scheyvens \& Russell, 
2012). Furthermore, a study conducted in Fiji on the impact of small-scale tourism enterprises on poverty alleviation in the country shows that small scale tourism enterprises make positive contributions to revenue generation, job creation and community development (Scheyvens \& Russell, 2012).

The definition of corporate governance exists according to various disciplines. According to Berle and Means (1932), the earliest definition of corporate governance is in connection with the protection of the interests of shareholders and has some roots in the question of separation between management and control. Generally, corporate governance can be seen as the relationships between management and shareholders. Further, the Cadbury Committee (Cadbury, 1992, p. 15) defines corporate governance as the system by which companies are directed and controlled. The OECD (2004) perceives corporate governance as more than an analysis of the effect of separation and control in a modern society thus defining it as dealing with the rights and responsibilities of a company's management, its board, shareholders and various stakeholders. In other words, corporate governance can be seen as codes and principles which typically focus on the relationship between management, the board of directors and the shareholders of listed companies. Deakin and Hughes (1997) summarize corporate governance as the relationship between the internal governance mechanisms of corporations and society's conception of the scope of corporate accountability. Previously, Shleifer and Vishny (1996) also saw corporate governance as the ways in which suppliers of finance to a firm assure themselves of getting a good return. Additionally, Keasey et al. (1997) define corporate governance as the structures, processes, cultures and systems that engender the successful operation of the organizations. Meanwhile, according to Ruin (2001), corporate governance is referred to as a collective group of people united as one body with the power and authority to direct, control and rule. In summary, it can be understood that corporate governance involves the relationships between many stakeholders and the management aspects.

A recent study conducted by Zainol Abidin et al. (2015) emphasized that there are several issues regarding corporate governance in TSMEs which must be given serious attention. They categorized these issues into three aspects namely the roles of corporate governance, the challenges of corporate governance and the significance of corporate governance to TSMEs. The roles of corporate governance consisted of four issues for instance composition of a Board, inducing more independent best practice, assessing resources for growth and introducing professional governmental practices. Additionally, the challenges of corporate governance in TSMEs included specific characteristics of the entrepreneur, the size of the organization, lack of corporate governance structure, insufficient access to financial resources, insufficient access to investment capital and lack of awareness on corporate governance matter. Further they also concluded that the significance of corporate governance to TSMEs can be acknowledged as better management practices, stronger internal auditing, greater opportunities for growth, prospects in obtaining funds, improving transparency and attracting capital at cheapest cost. Today, many firms and organizations are practicing a good governance mechanism to increase their performance. The adoption of best practices in corporate governance has a prominent place in the regulatory and developmental global agenda of capital markets. In fact, the adoption of best governance practices is particularly important in countries where, usually, ownership is well-defined, highly-concentrated, family-controlled and with an asset-oriented culture. Furthermore, the enforcement of corporate governance practices results in strict and stringent mechanisms which could dampen corporate entrepreneurship. To encourage 
managers to pursue goals that are considered desirable, various mechanisms are applied within the models of corporate governance. In this respect, mechanisms are viewed as effective if they encourage those who have decision-making roles in the operation of the company to make decisions that maximize shareholders' wealth.

In the process of practicing good governance, it is very important to understand the paradigmatic change to education. Knowledge, skills and competences in the educational paradigm would create specific value for potential employees (Matlovič \& Matlovičová, 2016). This eventually is the beginning for employees of TSMEs to clearly understand the significant of having good governance practice for the company. In their study, Matlovič and Matlovičová (2016) focused on the theoretical basis of paradigmatic change and presented new ways for educational paradigm to be implemented for Geography education in Prešov University. In the case of TSMEs, it is believed that education would contribute in assisting better understanding of best corporate governance practice at the university level. In designing a corporate governance system, it is important to include all the stakeholders in particular, the company and all interested parties. The system of governance could thus help or hinder internal corporate ventures. By aligning the interest of managers and all stakeholders, it is in the best interests of owners to resort to control mechanisms that move the operations of the firm to full efficiency. Several studies found that there are limited studies in the area with respect to SMEs mainly on developed economies (Bennett \& Robson, 2004; Eisenberg et al., 1998). This is based on the fact that it is crucial to examine corporate governance in the SME sector from the context of a developing economy. Abor and Biekpe (2007) reasoned that the perception of higher risk, informational barriers, and the higher costs of intermediation for smaller firms explain the reluctance of financial institutions to advance credit to SMEs. For example, some empirical studies in Ghana have established a relationship between measures of corporate governance and financial performance.

Abor and Biekpe (2007) sought to assess how the adoption of corporate governance structures affects the performance of SMEs in Ghana. A year later, another study was carried out to examine corporate governance practices of SMEs in Ghana and whether there is any linkage between these governance practices of SMEs and financial performance (Kyereboah-Coleman \& Amidu, 2008). They employed two levels of interaction to achieve these objectives. The first was an interview for a general understanding of governance issues in the SME sector and the subsequent design of a questionnaire for an exploration of the linkages between governance issues and firm financial performance by employing a linear model. The study revealed that governance structures in SMEs were jointly influenced by credit providers and business ethical considerations. Aguilera and Cuervo-Cazurra (2004) believed that the importance accorded to these mechanisms is reflected in some diverse initiatives aiming at explaining the good practices of the governance itself. Recently, the interest accorded to the mechanisms of governance and their effects on the companies' financial performance have taken a primary international dimension of first rank. It is worth noting that the ownership structure, the board of directors as well as the directors' characteristics constitute three central elements in the survey of the SMEs governance. The mechanisms of governance of the SMEs have for object not only the protection of the contribution of the shareholders but also the transactions between the enterprise and the different stakeholders, that it is the directors, the creditors, the salaried employees, the customers, the suppliers and, in a very general way, the social environment. The SMEs have met many obstacles of financial nature. In general, when they look for financing, they have access only to the credit banking, whereas their more important competitors can inquire 
the financial markets. The complexity of an organization grows with its size. As for the internal aspect, the majority of the directors are shareholders in the setting of the ownership structure (Charreaux, 1998). Indeed, the familial SME owners could benefit from giving a lot of its involvement to their directors. This implies that the enterprise could use the exceptional facilities and the capacities that the owner uses in order to succeed (Randoy \& Goel, 2003). The board of directors represents the main organ of control, complementary to the external mechanisms. The role of the board spreads to several functions within the SME: the administration of the enterprise, regaining some roles of surveillance, control of the directors and the setting up of the enterprise strategy, the organization of relations between the enterprise and its environment, the capitation of the external facilities, the recompense of the directors, their dismissal, and ratification and control of the important decisions taken by the direction (Van et al., 2006).

\section{THE FRAMEWORK}

Based on the previous literature review, nine elements are found to be significant for corporate governance practice in TSMEs. These elements are considered as best domains to be practiced by TSMEs in order to achieve performance excellence. Figure 1 presents the framework for corporate governance best practice in TSMEs.

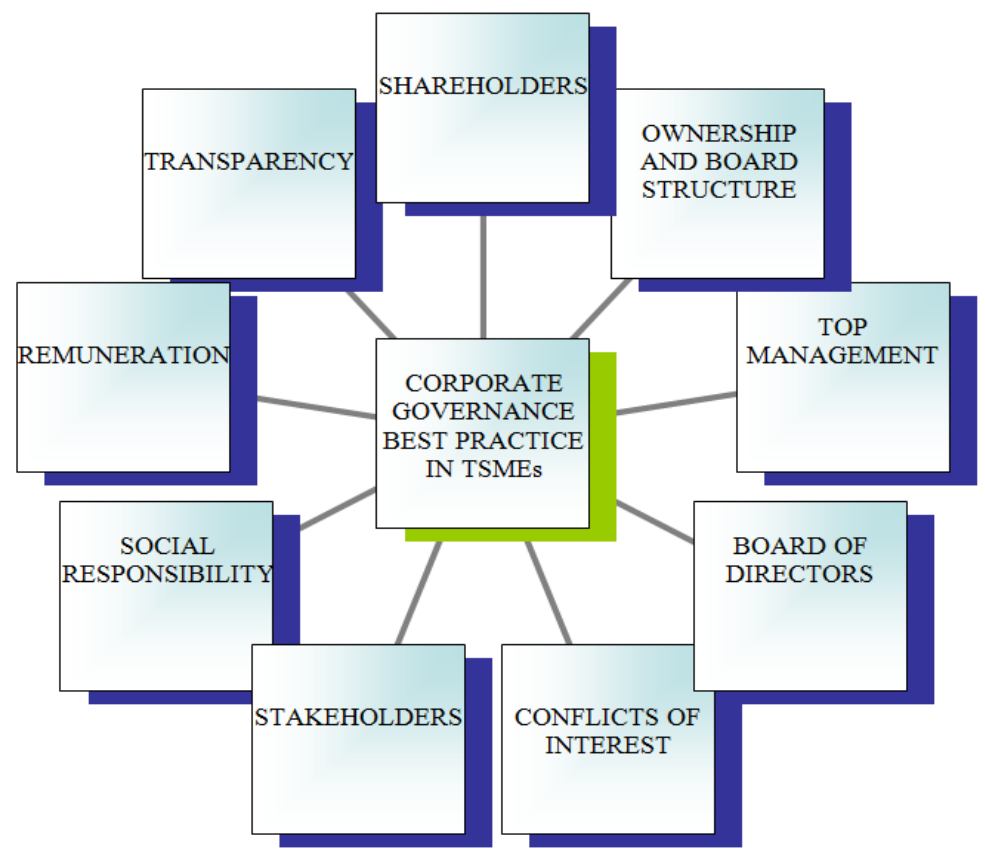

Figure 1. Framework of Corporate Governance Best Practice for TSMEs Derived from this Study

\section{DISCUSSION}

Generally, the literature in TSMEs and corporate governance suggests that good practice of corporate governance is a must in order for TSMEs to achieve performance excellence and eventually contribute to the country's economic growth. Nine elements are found in this study as good practice to be implemented in TSMEs. These nine elements are acknowledged as (1) Shareholders, (2) Ownership and Board Structure, (3) Top Management, (4) Board of Directors, (5) Conflict of Interest, (6) Stakeholders, (7) Social Responsibility, (8) 
Remuneration and (9) Transparency. Taking into account the shareholders as one of the elements for corporate governance best practice, is consistent to other studies such as Eisenberg et al. (1998), Randoy and Goel (2003) and Set (2013). Several questions which commonly derive from the element of shareholders as best practice of corporate governance regard the shareholders' right to take part in the company's meetings, have a say in the appointment and dismissal of the company's administrators and also have a say in evaluating the top management performance. Further, this element also consists of the shareholders right to have full timely access to the company's information, to be informed of the company's comprehensive management plan, knowing exactly who controls the company and any other firms they may control and also examine, approve or reject yearend financial statements and balance sheets. In addition, few other aspects which should also be included in this element are the establishment of fair compensation systems for board members, the establishment of principles of business ethics and the prohibition of payments of any household or personal expenses of shareholders with company funds.

On the other hand, ownership and board structure derive as best practice for corporate governance which is in line with few studies such as Abor and Biekpe (2007), Eisenberg et al. (1998) and Randoy and Goel (2003). Several aspects should be included in this element, for instance the benefits they received, incentives, decision making and balancing the power between the Chief Executive Officer (CEO) and chairman. As for the element for the top management, most literature suggests several aspects to be considered as best practices such as effort to achieve company's objective, ensures strict compliance with legal or statutory provisions, ensures the due and proper performance of statutory auditing functions and respects and enforces the rules of corporate governance adopted by the company. In line with previous literature (Aguilera \& Cuervo-Cazurra, 2004; Bennett \& Robson, 2004; Eisenberg et al., 1998; Van et al., 2006), it is also highlighted that the element for board of directors commonly included the number of members, outside or independent director, meetings, establishment of policies regarding human resources, advising members on auditing, hiring and compensation and appointment of the CEO. Further, the conflict of interest as good practice for corporate governance should consist of several matters, for instance, the establishment of procedures to ensure that company procurements of goods and services are consistent with principles of efficiency and transparency, the issue where under no circumstances may company executives grant any special compensation to members of the board, use unlawfully inside or privileged information to their own advantage or to protect their personal interests or those of any third parties, to use their standing position or relationship with the company to engage in politicking and also to bring family members into the company without regard for their qualifications or for established policies. Additionally, one of the best practices suggested to be included in the corporate governance for TSMEs is regarding stakeholders (Abor \& Biekpe, 2007; Randoy \& Goel, 2003). The stakeholders' element should involve the establishment of mechanisms for allowing its customers to make inquiries, suggestions and claims.

It should also consider the establishment of fair procedures for goods and services based on considerations of quality, pricing and performance, the company should be liable to the creditors for debts incurred according to the terms and conditions of corresponding agreements, the establishment of mechanisms for monitoring compliance with laws and regulations governing its line of business, designing mechanisms to ensure the fair treatment of the employees and finally, the establishment of mechanisms for passing benefits along to the surrounding community. The next element in corporate governance best practice is known as social responsibility. Most literature suggests that 
this element should contain strategies for preventing and minimizing environmental and human impacts and risks (Sampaio, et al., 2012; Scheyvens \& Russell, 2012). Additionally, it should also involve the promoting of sound environmental management and controlling the environmental impact of their operations, products and services. Further, social responsibility should also indicate that the company will report any irregularities observed within the company or in any other enterprises and at the same time would develop programs to improve the quality of life in their local communities.

As for the element regarding remuneration, it is emphasized that this element should consider four practical remuneration aspects such as the incentives given by the top management should ensure the alignment of the management and shareholders interest, the director's remuneration should be appreciable and reflect the responsibility and commitment of the directors, the remuneration for the executive director should link rewards to corporate and individual performance and finally the remuneration for nonexecutive directors should link rewards to experience and level of responsibilities. Eventually, the final element of best practice for corporate governance in TSMEs is regarding transparency. This element is consistent to various studies for instance Abor and Biekpe, 2007; Bennett and Robson, 2004; Chittithaworn et al., 2011; Eisenberg et al., 1998 and Kyereboah-Coleman and Amidu, 2008. In fact, this element is considered in most literature as the major element which should be given serious attention by the company and the Board of Directors. Corporate governance is about transparency; hence, the company which does not include this element in its practice might probably not implement corporate governance. Few aspects which should be acknowledged into this element are the disclosure of financial information to the company's shareholders, board members and statutory and other auditors, as well as to any interest groups, the disclosure of compensation systems established by the Boards of Directors, the statutory audits which are designed to protect the rights of shareholders and other investors and, as such, should be conducted in good faith, with no interference from CEO, members of the Board of Directors or shareholders and the establishment of appropriate, accessible information mechanisms such as businesses host web sites and electronic media (fax transmissions or e-mails).

\section{CONCLUSION}

Corporate governance practice is vital not just for bigger companies but mostly for the small companies and entrepreneurs. Hence, it should be practiced in TSMEs based on the fact that TSMEs play essential role in contributing to the country's economic growth, particularly in the case of Malaysia. This framework should be applied and adapted by TSMEs in Malaysia to achieve better and highly effective performance in managing the company. It would significantly assist the Board of Directors to manage and control the administration of the company as well as the members towards achieving the company's objective. By understanding the importance of the nine elements presenting best practice of corporate governance, the company should be able to manage not just the tourism products or services offered to the customers but mostly the members of the board. It is suggested that further studies should be undertaken to investigate the Board of Directors' perceptions regarding the framework of best practice for corporate governance in TSMEs. Another study could also be undertaken to determine whether these nine elements are of significant importance to the Board of Directors of TSMEs and which elements are considered the most vital, which consequently would lead to better performance of TSMEs.

\section{Acknowledgements}

This study is sponsored by the Ministry of Higher Education, Malaysia under the Fundamental Research Grant Scheme (FRGS) S/O Code 13028. 


\section{REFERENCES}

Abor, J. \& Biekpe, N. (2007). Corporate governance, ownership structure and performance of SMEs in Ghana: implication for financing opportunities. Corporate Governance, no. 7, vol. 3, p. 228-300.

Aguilera, R. V. \& Cuervo-Cazurra, A. (2004). Codes of good governance worldwide: what is the trigger? Organization Studies, no. 25, vol. 3, p. 415-443.

Akbaba, A. (2012). Business performance of small tourism enterprises: a comparison among three sub-sectors of the industry. Anatolia, no. 23, vol. 2, p. 177-195.

Bennett, R. J. \& Robson, P. J. A. (2004). The role of board of directors in small and medium-sized firms. Journal of Small Business and Enterprise Development, no. 11, vol.1, p. 95-113.

Berle, A. A. \& Means, G. C. (1932). The Modern Corporation and Private propriety. Revised edition 1967, New York: Harcourt, Brace et World, Inc.

Causevic, S. \& Lynch, P. (2013). Political instability and its influence on tourism development. Tourism Management, no. 34, p. 145-157.

Charreaux, G. (1998). Governance of SME-SMI. -PMI:Paris, Economica, pp. 109-116.

Chittithaworn, C., Islam, M. A., Keawchana, T. \& Yusuf, D. H. M. (2011). Factors affecting business success of small and medium enterprises (SMEs) in Thailand. Asian Social Science, no. 7, vol. 5, p. 180-190.

Deakin, S. \& Hughes, A. (1997). Comparative corporate governance: an interdisciplinary agenda. In Deakin, S. \& Hughes, A., Enterprise and Community: New Directions in Corporate Governance, Oxford: Blackwell Publishers.

Eisenberg, T., Sundgren, S. \& Wells, M.T. (1998). Larger board size and decreasing firm value in small firms. Journal of Financial Economics, no. 48, vol. 1, p. 35-54.

Keasey, K., Thompson, S. \& Wright, M. (1997). Introduction: the corporate governance problem: competing diagnoses and solutions. In Keasey, K., Thompson, S. \& Wright, M. (Eds), Corporate Governance: Economic and Financial Issues, Oxford: Oxford University Press, pp. 1-17.

Kyereboah-Coleman, A. \& Amidu, M. (2008). Examine the link between small business governance and performance: a case of small and medium scale enterprises in Ghana. Journal of African Business, no. 9, vol. 1, p. 121-143.

Matlovic, R. \& Matlovicova, K. (2016). The position of tourism and territorial marketing in the context of paradigmatic change to tertiary geography education in Slovakia. Geojournal of Tourism and Geosites, 18 (2), pp. 133-144.

Narayan, P. K., Narayan, S., Prasad, A. \& Prasad, B. C. (2010). Tourism and economic growth: a panel data analysis for Pacific Island countries. Tourism Economics, no. 16, vol. 1, p. 169-183.

Natarajan, G.S. \& Wyrick, D.A. (2011). Framework for Implementing Sustainable Practices in SMEs in the United States. Proceedings of the World Congress on Engineering 2011 Vol I. WCE, July 6 - 8, 2011, London, U.K.

Randoy, T \& Goel, S. (2003). Ownership structure, founder leadership, and performance in Norwegian SMEs: implications for financing entrepreneurial opportunities. Journal of Business Venturing, no. 18, 619-637.

Ruin, J. E. (2001). Essentials of Corporate Management. MICG. Malaysia.

Sampaio, A.R., Thomas, R. \& Font, X. (2012). Why are some engaged and not others? explaining environmental engagement among small firms in tourism. International Journal of Tourism Research, no. 14, vol. 3, p. 235.

Scheyvens, R. \& Russell, M. (2012). Tourism and poverty alleviation in Fiji: comparing the impacts of small and large-scale tourism enterprises. Journal of Sustainable Tourism, no. 20, vol 3, p. 417-436.

Set, K. (2013). Determining the Key Success Factors of Tourism Small and Medium-Sized Entreprises (TSMEs) in Malaysia. PhD Thesis. Newcastle Business School, University of Newcastle. Australia.

Shleifer, A. \& Vishny, R. W. (1996). A Survey of Corporate Governance, National Bureau of Economic Research Working Paper, No: 5554 quoted in Vessler, W., Khan F.R \& Sherman, H., April 1997, Going Public, A Corporate Governance Perspective. Working Paper, pp. 2.

Van, G., Heuvel, J. \& Voordeckers, W. (2006). Board Roles in Small and Medium-Sized Family Businesses: Performance and Importance. Belgium: Hasselt University, Faculty of Applied Economic Sciences, p 36.

Zainol Abidin, A., Mohd Shariff, N., Ibrahim, M. A. \& Yusof, N. (2015). Corporate governance in Malaysian small and medium-sized enterprises: review of research issues. Australian Journal of Basic and Applied Sciences, no. 10, vol. 11, p. 236-242.

*** Cadbury Committee (1992). Report of the Committee on the Financial Aspects of Corporate Governance, London: Gee Publishing, p. 15.

*** Dalberg Global Development Advisors. (2011). Report on Support to SME in Developing Countries through Financial Intermediaries.

*** OECD. (2004). OECD Principles of Corporate Governance. [Online] Available: www.oecd.com. OECD, 2004.

*** Small and Medium Enterprises Corporation Malaysia. (2012). Report obtained from the website. www.smecorp.gov.my.

Submitted:

26.01.2018
Revised:

31.05.2018
Accepted and published online 05.06.2018 